\title{
The impact of the pandemic covid-19 on the small industry of processing the "Krecek" crackers in Bantul Yogyakarta
}

\author{
Sutrisno* and Nanang Setiyo \\ Departement of Agribusiness, Universitas Muhammadiyah Yogyakarta, Indonesia
}

\begin{abstract}
Krecek" crackers are a popular food in Yogyakarta and its surroundings, made from cow, buffalo or goat skin. A "Krecek" cracker is usually processed as a complement to the Gudeg menu which is very popular in Yogyakarta. This study aims to determine total production, revenue, income, profit, R / C ratio, capital productivity, and labor productivity before and during the Covid -19 pandemic. The research was conducted in a small industrial center (home industry) processing "Krecek". This research was conducted by using the census method to 33 home industrial cracker processing "krecek" in production centers, in Segoroyoso, Pleret, Bantul. The results showed that during the Covid19 pandemic era, the processing of "krecek" decreased production by an average of $33.87 \%$, income decreased by $20.02 \%$, and profits decreased by $21.35 \%$. However, the RC ratio increased from 1.07 to 1.09 , labor productivity increased by $30.17 \%$ and capital productivity increased by $22.63 \%$. The conclusion of this research is that the "Krecek" cracker processing business during the Covid -19 pandemic has decreased production, income and profits, but it is still feasible.
\end{abstract}

\section{Introduction}

"Krecek" are crackers made from animal skins. These animals produce meat such as cattle, buffalo and goats. Animal skin as the basic material for the production of "Krecek" is a waste after the use of meat. These "Krecek" crackers are also known as "rambak". Although "rambak" crackers can be made from chicken or fish skin. "Krecek" contains about $63.90 \%$ protein (buffalo crackers) and $64.71 \%$ (beef crackers). Contains fatty acids of $31.81 \%$ (buffalo crackers) and $32.44 \%$ (beef crackers). The high fatty acid content is thought to be due to the oil frying process. "Krecek" is processed from animal skins by grading, washing, soaking, liming, cleaning, boiling, cutting, adding spices, drying, frying and packaging [1]. The most vital process in making "krecek" is soaking. This soaking process requires acid. For food safety, organic acids from lime are used [2]. The safety process in food production is important because it affects the health of consumers [3].

"Krecek" is very popular around Yogyakarta as a complement to the "Gudeg" menu. The culinary "Gudeg" is very famous and has become the identity of Yogyakarta. The majority of "Krecek" producers in Yogyakarta are small industries or micro industries. Micro industry is an enterprise in the form of a home industry. According to the Law of the Republic Indonesia Number 20 (2008), micro-enterprises are productive businesses owned by individuals and/or individual business entities that have micro-enterprise criteria.

\footnotetext{
*Corresponding Author : sutrisno_agrifp@umy.ac.id
} 
Meanwhile, small business is an independent productive economic business, which is carried out by individuals or business entities that are not subsidiaries or branches of companies that are owned, controlled, or become a part either directly or indirectly of medium or large businesses. Home industry operates on a small scale, with a nonprofessional workforce, small capital, and seasonal production [4]. However, that small and home industries have advantages in terms of flexibility compared to large businesses [5] The existence of home industries in Indonesia has a very important role in the economy, especially in terms of employment opportunities, income distribution, and economic development in rural areas [6]. In Yogyakarta, small industries or home industries producing "Krecek" are found in Bantul Regency, especially Pleret District. It is a legendary business passed down by parents and passed on from generation to generation. Before the Covid-19 pandemic, the "Krecek" industry was an established and growing industry.

The Covid-19 pandemic that started in Wuhan, eventually spread to almost 200 countries in the world, including Indonesia around April 2020. Although initially Covid-19 caused by the corona virus only caused mild symptoms like the common cold, this virus has grown to be more deadly [7]. In addition to treatment, various efforts are being made to reduce the transmission of the corona virus, including social distancing and avoiding crowds. The Indonesian government has implemented restrictions on social mobility with a lockdown. Places that have the potential to cause crowds of people are closed. Offices, schools, markets, malls, and restaurants and tourist attractions were eventually closed. People's activities are limited; working outside the home is replaced by working from home and schooling from home [8].

The covid-19 was impact in many sector such as agriculture and economic. In agricultural sector Covid-19 pandemic has an impact on reducing production by $5 \%$ [14]. On economic sector, this pandemic was impact many industries from the small sale until the large scale. One of the small industry in Jogja that has impact due to covid 19-pandemic is "Gudeg". "Gudeg" culinary tourism in Yogyakarta is very limited. The number of people visiting the "Gudeg" shop or restaurant is decreasing. This causes a decrease in the turnover of the "Gudeg" business. The decrease in demand for "Gudeg" affects the demand for "Krecek". On-site shopping habits turned into online ordering. Merchants "'Gudeg" and "Krecek" are not ready with online marketing. It is believed that Covid-19 will have an impact on reducing the income and profits of processing "Krecek" crackers . It is necessary to ask whether the "Krecek" processing business is still feasible to continue. This study aims to determine the impact of the Covid-19 pandemic on profits and business feasibility during the pandemic.

\section{Research Method}

\subsection{Research Location \& Respondents}

The study was conducted on 33 "Krecek" industries, using a descriptive analysis method. The research location is Segoroyoso Village, Pleret District, Bantul Regency, Yogyakarta Special Region Province. Pleret sub-district is the center of the "Krecek" industry in Bantul Regency. The determination of Segoroyoso Village was done intentionally based on the largest number of industries. There are 33 industries, all of which are used as respondents. Primary data was collected by interviewing respondents based on a list of questions (questionnaires). Secondary data were collected as a complement to the research results. 
The data analyzed are data on February 2020 (before the Covid-19 pandemic) and November 2020 (during the Covid-19 pandemic).

\subsection{Analysis Method}

The analysis used is the calculation of production costs, revenue, income, profits and business feasibility. The calculation of production costs uses the Sukartawi concept, which is also used by [9]. Business feasibility analysis uses the concept used by [10] and [11].

a. Total Cost calculated by the formula:

$$
T C=T E C+T I C
$$

Information:

TC : Total Cost (IDR),

TEC : Total Explicit Cost (IDR)

TIC : Total Implicit Cost (IDR).

b. Total Revenue calculated by the formula:

$$
T R=P x Q
$$

TR : Total Revenue (IDR),

$\mathrm{P}$ : Price per unit product (IDR),

Q : Total product (unit).

c. Net Revenue (Income) calculated by formula:

$$
N R=T R-T E C
$$

NR : Net Revenue (IDR),

TR : Total Revenue

TEC : Total Explicit Cost (IDR)

d. Profit calculated by the formula

$$
\pi=T R-T C
$$

$\pi \quad$ : Profit (IDR),

TR : Total Revenue (IDR)

TC : Total Cost (IDR).

\section{e. Feasibility Analysis}

The feasibility of industry was used three criteria, it was RC ratio analyses, labor productivity analyses, and the capital productivity analyses.

1) $R / C$ Ratio Analyses

Criteria:

$$
R / C \text { Ratio }=\frac{\text { Total Revenue }}{\text { Total } \text { Cost }}
$$

$\mathrm{R} / \mathrm{C}>1$ : business is feasible

$\mathrm{R} / \mathrm{C}=1:$ business is break even

$\mathrm{R} / \mathrm{C}<1$ : business is not feasible 
2) Labor productivity analyses

$$
L P=\frac{T R-R V O F-R O C}{F L C}
$$

Information:

$\begin{array}{ll}\text { LP } & \text { : Labor Productivity } \\ \text { TR } & \text { : Total Revenue } \\ \text { FLC } & \text { : Family Labor's Cost } \\ \text { RVOF } & : \text { Rent Value of Own Factory } \\ \text { ROC } & : \text { Rate of Own Capital } \\ \text { Criteria } & : \text { LP }>\text { local labor wages, business is feasible } \\ & \text { LP }<\text { local labor wages, usaha tidak layak untuk dijalankan }\end{array}$

3) Capitals Productivity Analyses

Information:

$$
C P=\frac{T R-R V O F-F L C}{T E C} \times 100 \%
$$

$\begin{array}{ll}\text { CP } & \text { : Capital Productivity } \\ \text { TR } & \text { : Total Revenue } \\ \text { FLC } & \text { : Family Labor's Cost } \\ \text { TEC } & \text { : Total Explicit Cost } \\ \text { RVOF } & \text { : Rent Value of Own Factory } \\ \text { Criteria } & : \text { CP }>\text { Bank Interest Rate, business is feasible } \\ & \text { CP }<\text { Bank Interest Rate, business is not feasible }\end{array}$

\section{Results and Discussion}

\subsection{Characteristics of Respondents}

The characteristics of the respondents in this study were descriptions of the owners of the "Krecek" processing industry in Segoroyoso according to age, gender, education level, business experience and second occupation. The full description is in Table 1.

\subsubsection{Gender}

Table 1 show that the majority of respondents (owners of the "Krecek" industry) are male. They are the head of the family. Home industry "Krecek" is a family business managed by the respondent with his wife and children. When the family workforce is overwhelmed, they recruit external workers. These external workers are paid according to the regional minimum wage. There was one female respondent because her husband died. He continues the business with his children. On certain jobs, she recruits external workers

\subsubsection{Age}

Table 1 show that the youngest respondent is 23 years old and the oldest is 60 years old. The majority of respondents are in the age range between $43-52$ years. Age classified as productive work ability. They started this business a long time ago with their parents. Some 
of the owners of this industry are younger. They become owners because they continue their parents' business

\subsubsection{Education Level}

In term of education level, it can be explained that the formal education level of the majority of respondents is elementary school (about 60\%). Their highest education level is high school. There are no respondents with a college education level. They consider that to manage the "Krecek" processing business, a higher education is not required.

\subsubsection{Cracker Business Experience}

Table 1 show that the experience of the respondents in managing the "Krecek" processing business is between 2 and 34 years. The majority ranged from 13 to 23 years. This shows that the majority have sufficient experience. Those who have less than 10 years of experience are beginners who start as new businesses or continue their parents' businesses.

Table 1. Characteristics of Respondents (owner of home industry)

\begin{tabular}{|l|c|c|}
\hline Gender & Frequency & Percent \\
\hline Male & 32 & 96.97 \\
\hline Female & 1 & 3.03 \\
\hline Total & 33 & 100 \\
\hline Age (year) & & \\
\hline $23-32$ & 5 & 15.15 \\
\hline $33-42$ & 7 & 21.21 \\
\hline $43-52$ & 17 & 51.52 \\
\hline $53-60$ & 4 & 12.12 \\
\hline Total & 33 & 100 \\
\hline Education Level & & \\
\hline Elementary School & 19 & 57.58 \\
\hline Junior High School & 8 & 24.24 \\
\hline Senior High School & 6 & 18.18 \\
\hline Total & 33 & 100 \\
\hline Cracker Business Experience (year) & & \\
\hline $2-12$ & 10 & 30.30 \\
\hline $13-23$ & 18 & 54.55 \\
\hline $24-34$ & 5 & 15.15 \\
\hline Total & 33 & 100 \\
\hline Second Occupation & & \\
\hline Farmer & 3 & 9.09 \\
\hline Cattle Farmer & 3 & 9.09 \\
\hline Trader & 6 & 18.18 \\
\hline No have & 21 & 63.64 \\
\hline Total & 33 & 100 \\
\hline & & \\
\hline & & \\
\hline & & \\
\hline
\end{tabular}

\subsubsection{Second Occupation}

About $60 \%$ of respondents who do not have a second occupation (side job). They make the processing business "Krecek" as the main business or main source of income. There are respondents who have side businesses as farmers, cattlers and traders. The majority of 
cattlers raise beef cattle. Cowhide as cut waste is used for "Krecek". Those who trade mostly sell "Krecek" and beef products, namely fresh meat, fresh bones and processed meat foods.

\subsection{The comparison of cost production "Krecek" before and during Pandemi Covid-19}

Production costs are explicit costs and implicit costs in the "Krecek" production process. Explicit costs include costs of production facilities (inputs), external labor costs, depreciation costs and other costs. Meanwhile, implicit costs that are not real are issued, but are calculated in the analysis of production costs. Implicit costs include family labor costs, rent value of self-factory, and interest on own capital.

Table 2. The comparison of explicit costs before and during pandemic Covid-19

\begin{tabular}{|l|c|c|c|}
\hline Costs & $\begin{array}{c}\text { Before Pandemic } \\
\text { (IDR) }\end{array}$ & $\begin{array}{c}\text { During Pandemic } \\
\text { (IDR) }\end{array}$ & $\begin{array}{c}\text { Decreasing } \\
\text { (\%) }\end{array}$ \\
\hline Inputs of production & $64,420,848$ & $41,156,121$ & 36.11 \\
\hline Other costs & $3,116,438$ & $1,705,917$ & 45.26 \\
\hline External Labors & $5,373,030$ & $3,558,939$ & 33.76 \\
\hline Depreciation & 314,193 & 314,193 & 0.00 \\
\hline Total Explicit Costs & $73,224,510$ & $46,735,171$ & 36.18 \\
\hline
\end{tabular}

Table 2 shows that during the Covid-19 pandemic, there was a decrease in explicit costs of $36.18 \%$. The decrease in explicit costs or real costs occurs in input costs, external labor costs and other costs. This happened because the total production of "Krecek" decreased. The decreased total demand of "Krecek" became the main reason for producers to reduce production. This is a strategy to survive in difficult times, especially due to the covid-19 pandemic, such as research by Fitrini and Iskandar [12] Because the amount of production decreases, the owner of the industry also reduces the use of external labor. The decrease in the amount of production also affects the calculation of implicit costs (table 3). Even though it is not real, the calculation of implicit costs follows the rules of variable costs. The amount of variable costs depends on the amount of production.

Table 3. The comparison of implicit costs before and during pandemic Covid-19

\begin{tabular}{|l|c|c|c|}
\hline \multicolumn{1}{|c|}{ Costs } & $\begin{array}{c}\text { Before Pandemic } \\
\text { (IDR) }\end{array}$ & $\begin{array}{c}\text { During Pandemic } \\
\text { IDR }\end{array}$ & $\begin{array}{c}\text { Decreasing } \\
(\boldsymbol{\%})\end{array}$ \\
\hline Family Labors & $2,538,220$ & $1,390,398$ & 45.22 \\
\hline Rent Value of Own Factory & $3,695,274$ & $3,695,274$ & 0.00 \\
\hline Interest on Own Capital & 146,449 & 93,470 & 36.18 \\
\hline Total Implicit Costs & $6,379,943$ & $5,179,142$ & 18.82 \\
\hline
\end{tabular}

\subsection{The comparison of "Krecek" business revenue before and during Pandemi Covid-19}

"Krecek" business revenue is the total value of the production of various skin crackers. The revenue depends on the total production items and the price of each item. Table 4 shows that the revenue of "Krecek" production includes revenue from buffalo crackers, cowhide crackers, goat crackers, raw crackers, sorting crackers and others. During the COVID-19 
pandemic, the production of skin crackers has decreased. This has an impact on decreasing business revenue. The average decreasing of revenue is 33.87 percent.

Table 4. The comparison of revenue before and during pandemic covid-19

\begin{tabular}{|c|c|c|c|c|c|}
\hline \multirow[t]{2}{*}{ Item } & \multicolumn{2}{|c|}{ Before pandemic } & \multicolumn{2}{|c|}{ During Pandemic } & \multirow{2}{*}{$\begin{array}{c}\text { Decreasing } \\
\text { of Revenue } \\
(\%)\end{array}$} \\
\hline & $\begin{array}{l}\text { Production } \\
(\mathrm{Kg})\end{array}$ & $\begin{array}{c}\text { Revenue } \\
\text { (IDR) }\end{array}$ & $\begin{array}{c}\text { Productio } \\
\text { n (Kg) }\end{array}$ & $\begin{array}{l}\text { Revenue } \\
\text { (IDR) }\end{array}$ & \\
\hline Buffalo crackers & 494.33 & $46,736,364$ & 282.39 & $26,329,455$ & 43.66 \\
\hline $\begin{array}{l}\text { Cowhide } \\
\text { crackers }\end{array}$ & 512.42 & $34,263,636$ & 398.48 & $27,468,182$ & 19.83 \\
\hline $\begin{array}{l}\text { Goats } \\
\text { crackers }\end{array}$ & 68.18 & $1,871,212$ & 42.42 & $1,160,606$ & 37.98 \\
\hline Raw cracker & 21.52 & $2,031,818$ & 14.38 & $1,266,212$ & 37.68 \\
\hline Sorting cracker & 21.82 & 475,121 & 9.31 & 248,303 & 47.74 \\
\hline Others & 5.91 & 31,515 & 1.62 & 7,621 & 75.82 \\
\hline Total Revenue & & $85,409,667$ & & $56,480,379$ & 33.87 \\
\hline
\end{tabular}

\subsection{The comparison of net revenue and profit of "Krecek" business before and during Pandemic Covid-19}

Net revenue is obtained from revenue minus explicit costs. Net revenue is also known as income of business. Profit of business is obtained from revenue minus explicit and implicit costs. Table 5 shows that net revenue decreased by about $20 \%$ and business profits decreased by about $21 \%$ as the impact of the COVID-19 pandemic.

Table 5. The comparison of net revenue and profit before and during pandemic covid-19

\begin{tabular}{|l|c|c|c|}
\hline \multicolumn{1}{|c|}{ Items } & $\begin{array}{c}\text { Before Pandemic } \\
\text { (IDR) }\end{array}$ & $\begin{array}{c}\text { During Pandemic } \\
\text { (IDR) }\end{array}$ & Decreasing (\%) \\
\hline Revenue & $85,409,667$ & $56,480,379$ & 33.87 \\
\hline Explicit Costs & $73,224,510$ & $46,735,171$ & 36.18 \\
\hline Implicit Costs & $6,379,943$ & $5,179,142$ & 18.82 \\
\hline Net Revenue & $12,185,157$ & $9,745,208$ & 20.02 \\
\hline Profit & $5,805,214$ & $4,566,065$ & 21.35 \\
\hline
\end{tabular}

\subsection{The comparison of feasibility of "Krecek" business before and during Pandemic Covid-19}

Table 6. The comparison of business feasibility before and during pandemic covid-19

\begin{tabular}{|l|c|c|c|}
\hline \multicolumn{1}{|c|}{ Analyses } & Before Pandemic & During Pandemic & Increasing (\%) \\
\hline RC-Ratio & 1.07 & 1.09 & 0.02 \\
\hline Labor Productivity (IDR) & 190,790 & 248,343 & 30.2 \\
\hline Capital Productivity (\%) & 8.13 & 9.97 & 22.6 \\
\hline
\end{tabular}

The feasibility of "Krecek" business is analyzed by calculating the RC Ratio, labor productivity and own capital productivity. Table 6 shows that the "Krecek" business in Pleret Bantul is classified as feasible based on the value of the RC ratio, labor productivity and capital productivity. Table 6 also shows that the value of the "Krecek" business feasibility has actually increased. Thus the "Krecek" business can still be continued even though it is in a state of crisis due to the covid-19 pandemic. These results are in accordance with the research of [13]. The RC Ratio value was 1.09 during the covid-19 pandemic; it was indicate that this business is still feasible to continue, because the RC ratio $>1$ is feasible [15]. 


\section{Conclusions and Recommendations}

The impact of the COVID-19 pandemic on the "Krecek" industry in Bantul is a decrease in production volume, production costs, revenue, net revenue and business profits. However, the value of business feasibility has actually increased. Thus, the "Krecek" industry in Bantul still deserves to be continued.

\section{References}

1. Amertaningtyas, D. Jurnal Ilmu-Ilmu Peternakan, 21(3), (2011)

2. Said, M. I., Murpiningrum, E., \& Asmi, N. ANDOC Published, (2016)

3. Purba, D. F., Nuraida, L., \& Koswara, S. Jurnal Standardisasi, 16 (2), (2014).

4. Ananda, R., \& Ashaluddin, A. Jurnal Online Mahasiswa. 3 (2) 2016).

5. Fatria, M. A., Jahrizal, J., \& Pailis, E. A. Junal Online Mahasiswa, 4 (1), (2017).

6. Kereh, D., Benu, N., \& Loho, A. In Cocos. 1 (8), (2017).

7. Yunus, N. R., \& Rezki, A. Jurnal Sosial dan Budaya Syar-i, 7 (3), (2020).

8. Supriatna, E. Jurnal Sosial dan Budaya Syar-i, 7 (3), (2020).

9. Pasau, M. A. B., Antara, M., \& Damayanti, L. Jurnal Agrotekbis, 3 (3), (2015).

10. Andriani, D. R. Agricultural Socio-Economics Journal, 15 (1), (2016)

11. Hanani, N., \& Hanafi, A. A. Agricultural Socio-Economics Journal, 12 (1), (2012).

12. Fitrini \& Slamet Iskandar. Respository Unsrat. Prosiding Persepsi III, (2018)

13. Rasdianah, \& Hafid, H. Open Acces Prosiding Haluleo University, (2015)

14. Wasito, H. Hermawan, J. Mulyono, E. Sirnawati, Y. Sihombing, and D. N. Ratri, E3S Web Conf. 306, 02016 (2021).

15. T. Buddhi Satyarini, Sutrisno, and F. Wira Kartika, E3S Web Conf. 232, (2021). 